\title{
The Relationship Between Macroeconomy Factors and Indonesian Banks' Financial Sustainability
}

\author{
Kenneth August Sahetapy \\ Postgraduate Student, Department of Accounting, Universitas Indonesia \\ kenneth.august@ui.ac.id
}

\begin{abstract}
This research analysed the relationship between macroeconomy factors and Indonesian banks' financial sustainability during 2011-2015. The macroeconomy factors used in this research are BI rate, inflation, money supply, and exchange rate. Meanwhile, to calculate banks' financial sustainability, FSR was used. The analysis was made on 6 groups of conventional banks using multiple regression with panel data method. The result of this research showed that as a whole, macroeconomy factors have a relationship with banks' financial sustainability. Partially, banks' financial sustainability has a relationship with BI rate and money supply.
\end{abstract}

Keywords: BI Rate, Inflation, Money Supply, Exchange Rate, Financial Sustainability.

\section{INTRODUCTION}

Banks and other financial institutions played a large and important role in a country's economic activities. The roles of banks are to collect funds from one party and channelling those funds towards another party that need those funds while also giving other bank services (Kasmir, 2000). Undang-Undang RI Nomor 10 Tahun 1998 further said that while doing its roles, banks can help improve the lives of many people.

To carry out its functions properly, which is to be an intermediary between those who have funds and those who need funds, a bank must have a good level of sustainability and growth. Financial sustainability is the ability of an organization to compare all its costs with income received from activities that were carried out (Almilia, Shonhaji, \& Angraini, 2009). One way to measure the level of sustainability of a bank is to use the financial sustainability ratio (FSR). FSR is a sustainability ratio that compares a company's financial income to its financial burden, which is useful in assessing the efficiency of an institution (Rizky, 2004). Furthermore, FSR can also be used to determine the level of financial growth of one's bank and in determining whether the bank can continue its financial performance or not. 
The financial sustainability of a company can be seen from its financial performance. One way to analyse the performance of a company is to look at its microeconomy conditions by evaluating its financial position in the financial statements (Rakasetya, Darminto, \& Dzulkirom, 2013). In addition, macroeconomy factors or factors outside the company also influence the increase or decrease of its performance directly and indirectly (Samsul, 2006). In line with those statements, Athanasoglou (2006), states that banks' profitability is a function of internal and external factors. Internal factors are bank-specific factors that determine profitability. Meanwhile, external factors are variables that do not have a direct relationship with the bank, however, these factors indirectly affect the economy and the law that can impact the performance of financial institutions.

Prior research in this topic mainly focus on microeconomy factors that covers multiple financial ratios such as capital ratio, earning asset ratio, profitability ratio, and liquidity ratio (Almilia, Shonhaji, \& Angraini, 2009; Rai \& Rai, 2012; Wahyuni \& Fakhruddin, 2014; Ashlin, 2011; Harjanti, 2011; Rizky, 2004) which yield mixed results. On the other hand, even though it is known that external factors can influence banks' financial sustainability, research on this topic using macroeconomy factors in Indonesia is limited (Almilia, Shonhaji, \& Angraini, 2009). Furthermore, this stream of research in Indonesia mainly uses data from the pre-financial crisis in 2008 and only uses one group of conventional banks. Therefore, this research uses macroeconomy factors, data from the post-financial crisis, and uses all six groups of conventional banks.

By using multiple regression and panel data method, it is found that as a whole, macroeconomy factors has a relationship with banks' financial sustainability. Partially, BI rate has a positive relationship with banks' financial sustainability, money supply has a negative relationship with banks' financial sustainability, while there is no relationship between inflation and exchange rate with banks' financial sustainability.

\section{LITERATURE REVIEW}

Macroeconomics

Macroeconomics is a term coined by Ragnar Frisch in 1933 that is applied to the study of a branch of economics about the economy as a whole or a broad economic field, such as national income, inflation, or unemployment (Siska, 2016). Macroeconomic can also be defined as a study of economic phenomena as a whole (Mankiw, 2008). Even though macroeconomic factors exist outside the firm, it still has an influence on the increase or decrease of the 
performance of the firm both directly or indirectly (Samsul, 2006). Macroeconomics factors that can influence firm's performance are general interest rate, inflation rate, exchange rate, money supply, etc.

BI Rate

The general interest rate in Indonesia is set by the central bank which is Bank Indonesia called BI rate. Siamat (2005) defines BI rate as a one-month interest rate announced periodically by Bank Indonesia that serves as a signal of monetary policy. Bank Indonesia will generally raise the $\mathrm{BI}$ rate if future inflation is estimated to exceed the estimation and vice versa. Because BI rate will be a reference for bank interest rates, this fluctuation in the BI rate can affect the profits of banking companies which can ultimately affect the financial sustainability of banking companies.

H1: BI rate will affect Indonesian banks’ financial sustainability.

Inflation

Barro (2008) defines inflation as a process of a general constant increase in prices that is related to market mechanism. This can be caused by various factors, among others, increased public consumption, excess of liquidity in the market that triggers consumption, and a non-smooth distribution of goods. High inflation is usually caused by the overheating of an economy, which is a condition when demand is higher than supply, which in turn cause an increase in prices. This overheating in the economy will also reduce the purchasing power of money and reduce the level of real income derived from its investment (Tandelilin, 2001). Since inflation plays a considerably large role in the financial economy, it is expected that it will affect banks' performance and in turn its financial sustainability.

H2: Inflation will affect Indonesian banks' financial sustainability.

Money Supply

According to the definition stated by Bank Indonesia (2016), money supply can be defined in two ways, money supply in the narrow sense (M1) or money supply in the broad sense (M2). M1 includes money held by the public and demand deposits in Rupiah, while M2 covers M1, quasi money (includes savings, time deposits in Rupiah and foreign currency, and current accounts in foreign currency), and securities issued by the monetary system owned by the domestic private sector with remaining term of up to one year. Meanwhile, Puspopranoto (2004) added another classification of money supply, which is money in the broadest sense 
(M3) which is the sum of M2 with all deposits in other financial institution. Growth in the money supply illustrates economic development, because usually if there is a growth in the economy, the money supply also increases (Almilia, 2004). This has a good impact on bank sustainability because, with a large amount of money in circulation, more and more potential financial transactions are carried out through banks.

H3: Money supply will affect Indonesian banks’ financial sustainability.

\section{Exchange Rate}

The exchange rate is the price of one country's currency that is measured or expressed in other currencies (Dessy \& Sujito, 2012). The exchange rate of a country's currency describes the conditions regarding supply and demand for the domestic currency itself compared with foreign currencies (Sugeng, 2010). The amount of excess demand for Rupiah will cause the price to rise. Conversely, excess demand against Rupiah will cause the price to decline. Due to the fact that most banks operate using Rupiah and other currencies, fluctuations in the Rupiah exchange rate will certainly have an impact on the financial sustainability of banks.

H4: Exchange rate will affect Indonesian banks' financial sustainability.

Conceptual Framework

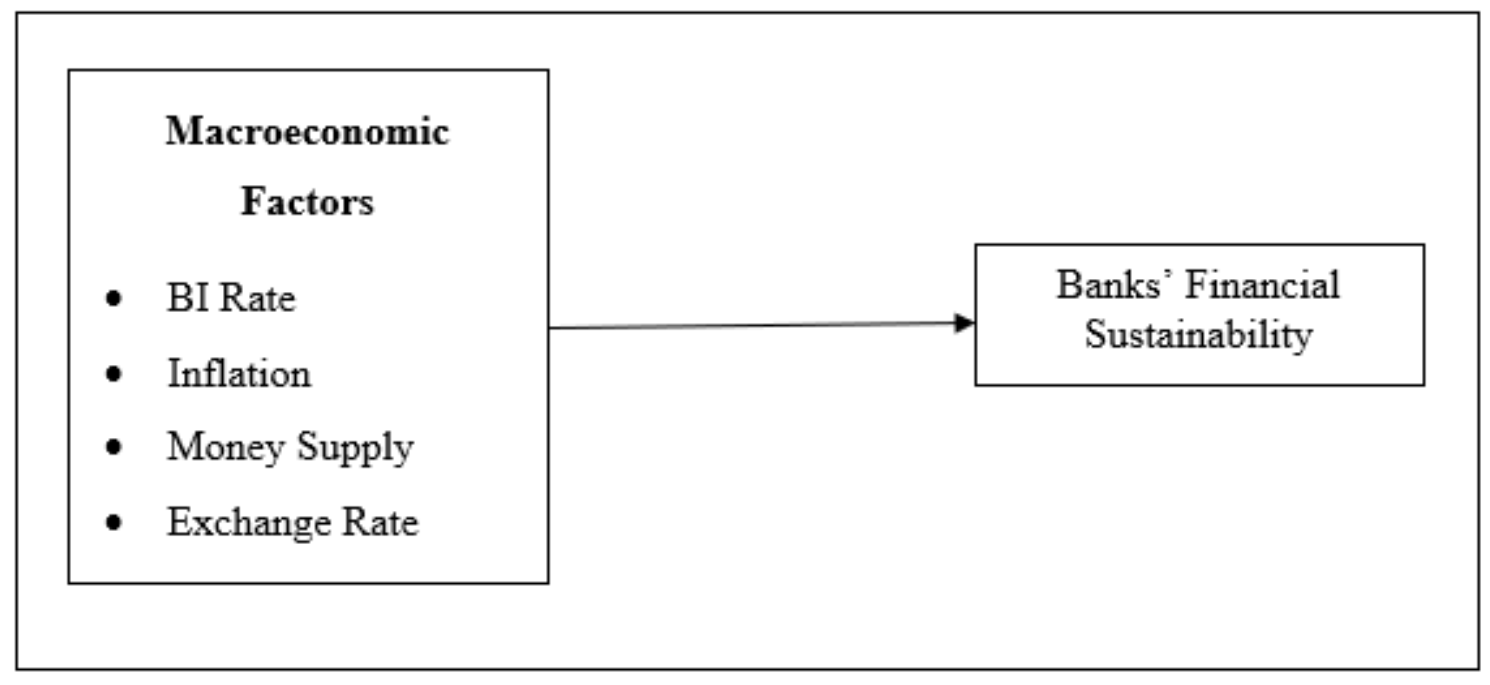

Figure 1. Conceptual Framework 


\section{METHODS}

Data, Sample, and Research Design

This study uses the population of all conventional commercial bank groups in Indonesia as the data, namely, State-Owned Banks (SOB), Foreign Exchange Commercial Banks (FECB), NonForeign Exchange Commercial Banks (NFECB), Regional Development Banks (RDB), Joint Venture Banks (JVB), and Foreign-Owned Banks (FOB). The observation period is from January 2011 to December 2015 with a total observation period of 60 .

The data used in this study are secondary data obtained from Statistik Perbankan Indonesia report published by Bank Indonesia, Stabilitas Ekonomi Keuangan Indonesia report published by Bank Indonesia, and the Bank Indonesia web site. The data are panel data which combines time series and cross-section data. The time-series data are monthly performance report of conventional banks in Indonesia that includes the financial sustainability data and complemented with reports of macroeconomic conditions that covers BI rate, inflation, money supply, and exchange rate. Meanwhile, the cross-section data used is the population data covering six categories of conventional banks. This research uses the fixed effect model of panel data.

This research conducts various classical assumption tests such as normality test, multicollinearity test, heteroscedasticity test, and autocorrelation test before testing the hypotheses. In testing the hypothesis, panel data regression method was used.

Research Variables

The research variables used in this study consisted of three types of variables namely the independent variable, the dependent variable, and the control variable.

The independent variable is the variable that influences or is the cause of the dependent variable. The independent variable in this research is macroeconomic factors such as BI rate (general interest rate determined by Bank Indonesia on a monthly basis), inflation (general increase in prices reported by Bank Indonesia), money supply (money supply in a broad sense (M2)), and exchange rate (monthly difference in exchange rate of Rupiah to US Dollar).

The dependent variable is the variable that is a variable whose value is affected due to the presence of an independent variable. The dependent variable in this research is the financial sustainability ratio (FSR), which is the ratio used to measure the sustainability of a bank in 
terms of the bank's financial performance. FSR consists of two components, namely financial expenses and financial income. This ratio can be formulated as follow:

$$
F S R=\frac{\text { financial income }}{\text { financial expense }} \times 100 \%
$$

The control variable is the variable that controls the variables so that the influence of the independent variable on the dependent variable cannot be influenced by external factors that are not examined. The control variables in this research are microeconomic factors that consist of return on assets ratio (ROA), capital adequacy ratio (CAR), operating expense to operating income ratio (BOPO), loan to deposit ratio (LDR), non-performing loan (NPL), and previous years' FSR. These control variables were factors that are proven to affect the financial sustainability of banks in previous research (Almilia, Shonhadji, \& Nanang, 2009; Rai \& Rai, 2012; Wahyuni \& Fakhruddin, 2014; Ashlin, 2011; Harjanti, 2011; Rizky, 2004).

Research Model

The research model is as follow:

$$
\begin{gathered}
F S R_{i t}=\left(\alpha_{0}+\alpha_{i}\right)+\beta_{1} R_{i t}+\beta_{2} I N F_{i t}+\beta_{3} \ln M 2_{i t}+\beta_{4} \Delta E R_{i t}+\beta_{5} R O A_{i t}+\beta_{6} C A R_{i t} \\
+\beta_{7} B O P O_{i t}+\beta_{8} L D R_{i t}+\beta_{9} N P L_{i t}+\beta_{10} F S R_{i t-1}+\varepsilon_{i t}
\end{gathered}
$$

Where:

$F S R=$ Financial Sustainability Ratio

$R=$ BI Rate

$I N F=$ Inflation

$\ln M 2=$ Natural logarithm of the money supply (M2)

$\Delta E R=$ Monthly difference in the exchange rate of Rupiah to US Dollar.

$R O A=$ Return on Asset

$C A R=$ Capital Adequacy Ratio

$B O P O=$ Operational expense to operational income ratio

$L D R=$ Loan to Deposit Ratio

$N P L=$ Non-Performing Loan

$i=1,2, \cdots, N ; N=$ number of bank groups

$t=1,2, \cdots, T ; T=$ number of months

$\varepsilon=$ error 


\section{RESULTS}

Before conducting the statistical tests, classic assumption tests such as normality test, multicollinearity test, heteroscedasticity test, and autocorrelation test were carried out. From the test results, it was found that the data did not have a classical assumption problem.

Descriptive Analysis

Descriptive analysis was used to describe the data used in this study. The result of descriptive data can be seen in Table 1. It covers the minimum, maximum, mean, and standard deviation of the data.

Table 1. Descriptive Statistics

\begin{tabular}{|c|c|c|c|c|}
\hline & Minimum & Maximum & Mean & $\begin{array}{l}\text { Std. } \\
\text { Deviation }\end{array}$ \\
\hline FSR (Combined) & 106.16 & 162.35 & 130.17 & 12.84 \\
\hline FSR (SOB) & 129.33 & 162.35 & 152.33 & 6.52 \\
\hline FSR (FECB) & 117.09 & 137.41 & 128.81 & 4.88 \\
\hline FSR (NFECB) & 110.56 & 126.51 & 116.87 & 4.53 \\
\hline FSR (RDB) & 122.11 & 157.46 & 133.55 & 8.51 \\
\hline FSR (JVB) & 106.16 & 135.60 & 124.80 & 8.10 \\
\hline FSR (FOB) & 108.22 & 135.77 & 124.67 & 5.15 \\
\hline BI Rate $(\%)$ & 5.75 & 7.75 & 6.77 & 0.77 \\
\hline Inflation (\%) & 3.35 & 8.79 & 5.89 & 1.54 \\
\hline Money Supply (mil) & $2,420,191$ & 4546,700 & $3,461,137.62$ & $643,028.45$ \\
\hline Exchange Rate (Rp/US\$) & $8,532.00$ & $14,396.10$ & $10,775.49$ & $1,760.35$ \\
\hline
\end{tabular}


During the research period, the highest FSR value is of the SOB with a mean of 152.32 percent, meanwhile the lowest FSR value is owned by the NFECB with a mean of 116.87 percent. Because the number is above 100 percent, this shows that the FSR of the banks is quite good. The lowest value of BI Rate is 5.75 percent from February 2012 to March 2013 and the highest value is 7.75 percent in November to December 2014, with an average value of 6.77 percent and a standard deviation of 0.77 percent. Inflation has a range of 3.35 percent in December 2015 to 8.79 percent in August 2013, with an average value of 5.89 percent and a standard deviation of 1.54 percent. The money supply had the lowest value of 2,420,191 billion in February 2011 and the highest value of 4,546,700 billion in December 2015, with an average value of 3,461,137.62 billion and a standard deviation of 643,028.45 billion. The lowest value of exchange rate is $\operatorname{Rp~8,532.00~in~August~} 2011$ and the highest value is Rp 14,396.10 in September 2015, with an average value of Rp 10,775.49 and a standard deviation of 1,760.35.

Hypothesis Test

The results of the regression of the model performed by the Fixed Effect Model method can be seen in Table 2.

\section{Table 2. Analysis of the Model}

\begin{tabular}{crrrrr}
\hline \hline Variable & Coefficient & Std. Error & t-Statistic & Prob. \\
\hline \hline C & 135.7680 & 67.97117 & 6.749450 & 0.0000 & \\
BIRATE & 1.109240 & 0.441864 & 2.510362 & 0.0125 & $* *$ \\
INFLATION & -0.117111 & 0.155584 & -0.752723 & 0.4521 & \\
LNM2 & -11.19887 & 1.859908 & -6.021195 & 0.0000 & $* * *$ \\
DER & $7.45 \mathrm{E}-05$ & 0.000894 & 0.083368 & 0.9336 & \\
ROA & 0.709217 & 0.520418 & 1.362782 & 0.1738 & \\
CAR & -0.019765 & 0.086148 & -0.229433 & 0.8187 & \\
BOPO & -0.257903 & 0.031384 & -8.217740 & 0.0000 & $* * *$ \\
LDR & 0.078943 & 0.036310 & 2.174116 & 0.0304 & $* *$ \\
NPL & -0.219549 & 0.551827 & -0.397858 & 0.6910 & \\
FSR $\mathrm{t}-1$ & 0.593704 & 0.038376 & 15.47090 & 0.0000 & $* * *$ \\
Fixed Effects & & & & & \\
(Cross) & & & & & \\
SOB-C & 8.789556 & & & &
\end{tabular}


FOB-C

Effects Specification

Cross-section fixed (dummy variables)

$\begin{array}{llll}\text { R-squared } & 0.929275 & \text { Mean dependent var } & 130.1713 \\ \text { Adjusted R-squared } & 0.926191 & \text { S.D. dependent var } & 12.84517 \\ \text { F-statistic } & 356.1772 & & \\ \text { Prob(F-statistic) } & 0.000000 & & \end{array}$

From the results, we find that the coefficient of determination (adjusted $\mathrm{R}^{2}$ ) of 0.926 which means that this model can explain the 92.6 percent of the variations in the FSR. Meanwhile, the remaining 7.4 percent is explained or influenced by other factors outside the model.

The overall model test is valid at a significant level of one percent as indicated by the F-statistic value of 356.177 and p-value of 0.000 . This means that as a whole, macroeconomic factors affect FSR significantly.

From the partial test, it is found that two out of the four macroeconomic factors affect FSR significantly. BI rate affects FSR at five percent significant rate and money supply affect FSR at one percent significant rate. On the other hand, inflation and exchange rate have no significant effect on FSR. Therefore, the first and third hypotheses are accepted, while the second and fourth hypotheses are rejected

\section{DISCUSSION}

BI Rate

Based on the estimation results, BI rate has a significant influence on the financial sustainability of Indonesian banks at five percent significant level with a coefficient of 1.11. This means that if there is an increase in the interest rates by one percent, then the condition of banking financial sustainability will increase by 1.11 percent assuming that the other independent variables remain constant.

The estimation results during this research period explain that the BI rate or general interest rate set by the central bank can directly affect the profits of banks which will ultimately affect the financial sustainability of banks. 


\section{Inflation}

From the research results, it is found that inflation does not have a significant influence on the financial sustainability of Indonesian banks. On further observation, it can be seen that even though it is not significant, the relationship between inflation and the FSR of banks are negative. This shows that there are indications that explain that if there is an increase in the value of inflation, the value of the FSR will decrease.

The estimation results of this research may be explained due to the relatively stable inflation rate at walking inflation $(<10 \%)$. This low and stable inflation value may be the main cause of why inflation shows no effect on the financial sustainability of banks.

\section{Money Supply}

The results of this research showed that the money supply has a significant influence on the financial sustainability of banks at a significant level of one percent with a coefficient of 11.20. This means that if there is an increase in the money supply by one percent, it will cause a decrease in the condition of financial sustainability of banks by 11.20 percent under the assumption that the other independent variables are constant.

This shows that the money supply affects the financial condition of banks because when the money supply increases, the market tends to deposit more money in the banks and borrow less from the banks. This results in an increase in banks' costs and a reduction in banks' income which will affect the profitability of banks and ultimately its financial sustainability.

\section{Exchange Rate}

Based on the results, during the research period, changes in the exchange rate do not have a significant effect on financial sustainability of banks in Indonesia. However, the direction of relationship between the two shows a negative relationship. This indicates that if there is an increase in the changes in exchange rate, there will be a decrease in the financial sustainability of Indonesian banks.

This results that show that exchange rates fluctuations do not affect the sustainability of banks' financial sustainability is due to the fact that the changes in exchange rate occurs slowly and is smooth during the research period. The absence of drastic changes in the exchange rate whether it is a sudden major increase or decrease makes it easy for banks to adapt to the conditions and make an adjustment without compromising their financial sustainability. 
Individual Effect

The fixed-effect model can explain the different characteristics of each individual (bank group) within the value of intercept. Individual effects in the model show the different FSR characteristics of the bank groups and are included as part of the intercept in interpreting the model for each bank group. Fixed effects of each bank group for the estimated results of the model can be seen in Table 3 .

\section{Table 3. Fixed Effect of Each Individual Banks on the FSR Model}

\begin{tabular}{|l|l|l|}
\hline No. & Individual & Effect \\
\hline 1 & State-Owned Banks & 144.5576 \\
\hline 2 & Foreign Exchange Commercial Banks & 136.3389 \\
\hline 3 & Non-Foreign Exchange Commercial Banks & 131.5811 \\
\hline 4 & Regional Development Banks & 137.0453 \\
\hline 5 & Joint Venture Banks & 132.5317 \\
\hline 6 & Foreign-Owned Banks & 132.5535 \\
\hline
\end{tabular}

Based on the fixed effects of each bank group, every group has an FSR value greater than 100 percent. The FSR value above 100 percent means that the banks are able to survive financially in the future because it generates more revenue compared to their expenditure.

From the estimation results, the bank group with the highest value of FSR is the SOB, followed by RDB, FECB, JVB, and the last is the NFECB. SOB has the highest FSR value because it is owned by the government and part of the wealth generated by the state is stored in these banks which cause their income to be quite large.

RDB has the second-best financial sustainability after state-owned banks. This is because the goal of RDB is to mobilise funds in the regional area in developing those areas. Because of this, government funds that are used to develop the region tends to be stored in these banks. In third to fifth place are FECB, FOB, and JVB. Compared with SOB and RDB which can get funds from the government, these three banks do not have such treatment. However, the three of them have an advantage over NFECB which is in the last position because all three do foreign exchange transactions, while NFECB does not.

\section{Conclusion}

The purpose of this research is to see whether macroeconomic factors have a relationship with financial sustainability of banks in Indonesia. The results showed that two of the observed factors, namely, BI rate and money supply has a positive and negative relationship with banks' 
financial sustainability respectively. Meanwhile, inflation and exchange rate have no significant relationship with banks' FSR. This result can have financial institutions, specifically banks, to pay attention to the two macroeconomic factors, BI rate and money supply, and to adjust along with the changes in these two factors as it has a relationship with their financial sustainability.

This study is limited due to the fact that it only covers conventional banks in Indonesia. As Indonesia is the country with the largest number of Islam population in the world, there are a substantial number of banks that did not operate in a conventional way but in way of sharia called the sharia bank. Future research may include this group of banks as they operate differently compared to conventional banks and may garner different results. Future studies may also include other macroeconomic factors such as the government's regulation or others to complement this research.

\section{REFERENCES}

Almilia, L. S. (2004). Analisis faktor-faktor yang mempengaruhi kondisi financial distress suatu perusahaan yang terdaftar di Bursa Efek Jakarta. Jurnal Riset Akuntansi Indonesia, 7(1), 1-22.

Almilia, L. S., Shonhaji, N., \& Angraini. (2009). Faktor-faktor yang mempengaruhi financial sustainability ratio pada bank umum swasta nasional non devisa periode 1995-2005. Jurnal Akuntansi dan Keuangan, 11(1), 42-52.

Ashlin, B. N. (2011). Analisis faktor-faktor yang mempengaruhi financial sustainability ratio pada bank umum swasta nasional devisa periode 2003-2009. Skripsi Universitas Diponegoro.

Bank Indonesia. (2016). Perkembangan uang Beredar. Diambil kembali dari Bank Indonesia web site: http://www.bi.go.id/id/publikasi/perkembangan/Default.aspx

Barro, R. J. (2008). Macroeconomics: A Modern Approach. Mason: Thomson/Southwestern.

Dessy, \& Sujito. (2012). Pengaruh nilai tukar Rupiah, tingkat SBI, dan inflasi terhadap indeks harga saham gabungan di BEI periode tahun 2006-2010. Jurnal Ilmiah USM, 11(2), 107-116.

Harjanti, R. S. (2011). Analisis pengaruh rasio-rasio keuangan terhadap prediksi kebangkrutan bank. Skripsi Universitas Diponegoro.

Kasmir. (2000). Manajemen Perbankan. Jakarta: Rajawali Press.

Mankiw, G. (2008). Principles of Macroeconomics. Mason: South-Western Cengage Learning. 
Puspopranoto, S. (2004). Keuangan Perbankan dan Pasar Keuangan. Jakarta: Pustaka LP3ES.

Rai, A. K., \& Rai, S. (2012). Factors affecting financial sustainability of microfinance institutions. Journal of Economics and Sustainable Development, 3(6), 1-5.

Rakasetya, G. G., Darminto, \& Dzulkirom, M. (2013). Pengaruh faktor mikro dan faktor makro ekonomi terhadap harga saham perusahaan mining dan mining services yang terdaftar di Bursa Efek Indonesia (BEI) periode 2008-2011. Jurnal Administrasi Bisnis, 6(2), 112.

Rizky, A. (2004). Analisis faktor-faktor yang mempengaruhi financial sustainability ratio pada Bank Rakyat Indonesia dan Bank Danamon. Skripsi STIE Perbanas Surabaya.

Samsul, M. (2006). Pasar Modal dan Manajemen Portofolio. Jakarta: Penerbit Erlangga.

Siamat, D. (2005). Manajemen Lembaga Keuangan. Jakarta: Fakultas Ekonomi Universitas Indonesia.

Siska, Y. (2016). Konsep Dasar IPS. Yogyakarta: Penerbit Garudhawaca.

Sugeng. (2010). Pengaruh dinamika penawaran dan permintaan valas terhadap nilai tukar Rupiah dan kinerja perekonomian Indonesia. Buletin Ekonomi Moneter dan Perbankan, 311-354.

Tandelilin, E. (2001). Analisis Investasi dan Manajemen Portofolio. Yogyakarta: BPFE Yogyakarta.

Wahyuni, S., \& Fakhruddin, I. (2014). Analisis faktor-faktor yang mempengaruhi ratio perbankan syariah di Indonesia. Seminar Nasional dan Call for Paper Program Studi Akuntansi-FEB UMS, 113-126 